City University of New York (CUNY) CUNY Academic Works

\title{
Are COVID-19 Vaccine Boosters Needed? The Science behind Boosters
}

Rachel M. Burckhardt

American Academy of Microbiology

John J. Dennehy

CUNY Queens College

Leo L. M. Poon

University of Hong Kong

Linda J. Saif

The Ohio State University

Lynn W. Enquist

Princeton University

\section{How does access to this work benefit you? Let us know!}

More information about this work at: https://academicworks.cuny.edu/qc_pubs/507

Discover additional works at: https://academicworks.cuny.edu

This work is made publicly available by the City University of New York (CUNY).

Contact: AcademicWorks@cuny.edu 
This is an open-access article distributed under the terms of the Creative Commons Attribution 4.0 International license.

\section{Are COVID-19 Vaccine Boosters Needed? The Science behind Boosters}

3

4

$5 \quad{ }^{a}$ American Academy of Microbiology, Washington, DC, USA

6 biology Department, Queens College and The Graduate Center of The City University of New York, New 7 York, USA

8 'School of Public Health \& HKU-Pasteur Research Pole, LKS Faculty of Medicine, The University of Hong 9 Kong, Hong Kong, China

${ }^{d}$ Center for Food Animal Health, Department of Animal Sciences, College of Food, Agricultural and Environmental Sciences, OARDC, Veterinary Preventive Medicine Department, College of Veterinary Medicine, The Ohio State University, Wooster, Ohio, USA

e Department of Molecular Biology, Princeton University, Princeton, New Jersey, USA

*corresponding author: lenquist@princeton.edu

Running Title: Science of COVID-19 Boosters

\section{Authors' ORCID numbers}

RMB: 0000-0001-6290-2534

JJD: 0000-0002-9678-4529

LLMP: 0000-0002-9101-7953

LS: 0000-0002-3224-9009

LWE: 0000-0001-9968-8586

The views expressed in this Commentary do not necessarily reflect the views of the journal or of ASM. 


\section{Abstract}

Waning vaccine-induced immunity coupled with the emergence of SARS-CoV-2 variants has led to increases in breakthrough infections, prompting consideration for vaccine booster doses. Boosters have been reported to be safe and increase SARS-CoV-2-specific neutralizing antibody levels, but how these doses impact the trajectory of the global pandemic and herd immunity is unknown. Information on immunology, epidemiology and equitable vaccine distribution should be considered when deciding the timing and eligibility for COVID-19 vaccine boosters.

The global impact of the COVID-19 pandemic has been unprecedented, but so too has the speed of development and efficacy of vaccines for COVID-19. Less than a year from first identifying SARS-CoV-2 as the causative agent of COVID-19, multiple safe and highly effective vaccines were authorized for use around the world. But the longevity of vaccine-induced immunity is unknown, sparking debate on the need for "booster" vaccine doses in the hopes these will increase protection from SARS-CoV-2 infection and disease. Fears of waning immunity and the emergence of variants of concern (VOC) have fueled this debate. But deciding who should receive boosters and when are not easy questions to answer, especially given global vaccine distribution inequity. To make a decision, scientists must take into consideration known data on vaccines and immune memory, public health, epidemiology and ethics for diverse age ranges and socioeconomic groups.

\section{SARS-CoV-2 Vaccines Induce Robust and Protective Immune Responses, Even Against Viral Variants} A plethora of vaccines to SARS-CoV-2 were developed in an unprecedented rapid time frame. They included conventional inactivated (Sinovac, SinoPharm), adenovirus (Ad) vectored (Gamelaya, J\&J Janssen, AstraZeneca) and mRNA vaccines (Pfizer, Moderna). In the randomized clinical trials, their 
Burckhardt, et al.

efficacy against severe disease ranged from 59 to >95\%, but was lower against mild or asymptomatic disease ( 47 to $94 \%)(1,2)$. The mRNA vaccines showed consistently higher efficacy rates, but they elicited lower neutralizing antibodies (NAbs) titers in those $>70$ years at 6 months post vaccination (30\% no NAbs) $(2,3)$. In a Pfizer mRNA vaccine 6-month cohort in Israel, lower IgG Ab levels, especially in those $>60$ years, were correlated with subsequent infection (4).

Both the Ad vector and mRNA vaccines were engineered to express the pre-fusion spike protein (S) to induce NAbs. Both vaccine types stimulated effective innate immune responses (adjuvant effects) leading to enhanced adaptive immune responses. mRNA and Ad vector vaccines induced serum IgG S and receptor-binding domain (RBD) binding $A b$ and NAbs. These Ab responses generally were highly correlated and the Abs persisted for at least 6 months (2, 3, 5). Primarily S-specific Th1 and T follicular helper (Tfh) CD4+ T cells, with lower CD8+ T cell responses and persisting memory $T$ and $B$ cells were also documented in mRNA vaccinees (6). Emerging data from non-human primates (NHP) and vaccinees suggest that as for most other licensed vaccines, NAbs may be a potential correlate of protection (7-9). Serum Abs are produced by short-lived plasmablasts leading to the early peak of Ab responses that are then maintained by long-lived plasma cells (10-12). Multiple studies have documented 5 to $10-$ fold decreased serum IgG Abs within 5 to 6 months after mRNA vaccination (10,12), but serum IgG and NAb were detectable for 10 months in mild COVID-19 cases (13). Data from long-term follow-up studies of vaccinated individuals are yet to be released, but B and T cell responses can still be detected in vaccinees for at least 6 months after the second dose $(5,14)$. Additionally, a recent study demonstrated that the durability of vaccine-induced B or T cell responses in recovered COVID-19 individuals was similar to those of uninfected vaccinated individuals (14). Moreover, after mRNA vaccination or natural infection, the memory B cells induced continued to evolve in germinal centers with increasing levels of somatic hypermutation and Abs of increased affinity. These memory B cells persist longer term and are essential for recall secondary Ab responses to protect against reinfection (5, 10-12, 14-16). Notably, 
Burckhardt, et al.

Science of COVID-19 boosters

memory B cell expressed Abs had greater potency and breadth after natural infection compared with mRNA vaccination $(10,15,16)$. This may explain in part why natural infection conferred a higher level of protection against $S$ variants in some studies $(10,17)$. In contrast, an epidemiologic analysis of U.S. patients hospitalized with COVID-19-like illness and whose previous infection or mRNA vaccination accrued 90-179 days earlier found convalescent but unvaccinated patients were 5.49-fold more likely to have laboratory confirmed COVID-19 than mRNA vaccine recipients with no prior documented infection (19.75-fold higher if >65 years) (18). However, differences from the Israeli retrospective cohort study included: protection against infection (any SARS-CoV-2 positive test) vs protection against hospitalization, and a longer interval of 6-month vs 90-179 days prior to mRNA vaccination or infection, respectively.

Emergence of SARS-CoV-2 variants of concern with multiple substitutions in key Ab epitopes of the $\mathrm{S}$ glycoprotein may compromise immunity by partial escape from NAbs. Multiple studies suggest equivalent NAbs against the Alpha (B.1.1.7) variant, but several-fold reduced NAbs to the Gamma (P.1) and Delta (B.1.617.2) variants vs. original strains in sera of vaccinated or recovered individuals. In most studies, NAb titers were lowest against the Beta (B.1.351) variant, but all variants were neutralized to a variable extent attributable to the polyclonal $\mathrm{Ab}$ responses induced $(3,12,19)$. In contrast, $\mathrm{T}$ cell responses induced by mRNA vaccines or natural infection were not substantially affected by the variant substitutions (20). CD4+ T cells from recovered individuals mounted a broader antigen-specific response across the structural and accessory gene products, whereas the CD8+ T cells are predominantly nucleocapsid-specific while spike-specific responses are substantially lower in frequency (20). Potentially these CD8+T cells against the nucleocapsid $(\mathrm{N})$ may also contribute to immunity after natural infection, since these $\mathrm{N}$-specific responses, which are not induced by mRNA or Ad vector vaccines, may be more highly conserved against VOCs (20). 
Burckhardt, et al.

Science of COVID-19 boosters

The half-life of SARS-CoV-2 NAbs in recovered COVID-19 individuals is a few months, depending on disease severity $(12,13,19)$. Although these antibody responses wane rapidly, SARS-CoV-2-specific B and T cell memory responses can still be detected at least 1 year after the infection $(12,16,21)$. Similar waning of antibody response can also be found in non-infected vaccinees. Of interest, modeling of genetic traits between SARS-CoV-2 and the 5 other human coronaviruses to estimate Ab decline and the probability of reinfection revealed short-lived immunity of 3 months to 5 years (median 16 months) after peak $A b$ titer (22). Waning of Ab-mediated protection and the emergence of variants is consistent with occurrence of reinfections after 8 months in convalescent individuals infected with the Gamma variant (23) and vaccine breakthrough infections by variants $(4,24)$. However, despite lower NAb titers against variants, mRNA and other vaccines protected against most hospitalizations and deaths, including those resulting from infection with the Delta variant $(5,25)$. Whether the variants contribute to reduced symptomatic protection in vaccinees ("breakthrough infections") and convalescents is an important unanswered question.

Those individuals with lower initial SARS-CoV-2 Ab responses (elderly, immunocompromised) and whose $A b$ responses have waned after 6 months may be at increased infection risk. The elderly, who are the most susceptible to COVID-19 disease and deaths, have more restricted Ab and naïve T cell repertoires that likely constrain their immune responses (12). The increased transmissibility of the Delta variant along with the lower initial magnitude and waning Ab responses appear to have contributed to vaccine breakthrough infections, especially for severe cases in elderly and those with co-morbidities (4, 24), or immunocompromised individuals (26). These data prompted recommendations for booster vaccine doses for these vulnerable groups.

Importantly, infected vaccinees still shed and transmitted the virus, more so for the Delta than the Alpha variant (27), although of shorter duration and with lower amounts of infectious virus (28-30). Thus, virus transmission was reduced, but not eliminated by the current vaccines. An explanation is that 
Burckhardt, et al.

Science of COVID-19 boosters

the current parenteral vaccines induce mainly serum IgG Abs, highly effective against prevention of systemic or lower respiratory tract (LRT) infections (reduce severe disease and hospitalizations), but less effective at blocking virus infection of the oral cavity and upper RT (URT) to prevent virus shedding and transmission. Studies of mRNA 1273 vaccine in challenged NHP confirmed that lower serum S Ab levels were required to reduce virus replication in the LRT versus the URT (7). Likewise mRNA vaccinees had fewer S-specific T cells expressing longevity (CD127) or nasopharynx homing markers compared with convalescents (31). These findings coupled with the time needed for antigen re-stimulation of vaccineinduced memory $\mathrm{T}$ and $\mathrm{B}$ cells to evoke secondary immune responses (12), may enable the highly transmissible variants to infect the URT and transit to the LRT in vulnerable patients or those with waning serum Abs, increasing disease risk. Future vaccines that induce broadly reactive mucosal IgA and serum IgG NAbs and augment T cell repertoires may provide enhanced protection against both disease and transmission after exposure to variants (32).

\section{Known Impact of SARS-CoV-2 Vaccine Booster Doses}

Several publications have described the impact of SARS-CoV-2 vaccine booster on human immune responses (33-37). However, many primarily targeted specific groups (e.g., elderly or immunocompromised individuals) and analyzed different vaccine types. Some of these studies included only a small number of participants. With the exception of antibody neutralization, our understanding of immune correlates of SARS-CoV-2 protection is limited $(7-9,38)$. In addition, the minimal NAb level required for preventing infection or severe clinical outcomes and the importance of vaccine-induced memory B and T cells against SARS-CoV-2 are yet to be fully determined. Thus, the findings of these studies should be interpreted with caution and not extrapolated to the entire human population. Different types of COVID-19 vaccines including mRNA, viral vector, inactivated and proteinbased vaccines are used as boosters $(33,36,38-41)$. In general, a booster dose can substantially increase 
Burckhardt, et al.

Science of COVID-19 boosters

NAb levels or its surrogate markers (e.g., anti-spike IgG) against SARS-CoV-2. A booster dose also helps stimulate SARS-CoV-2 Abs in those who did not respond to a standard vaccine, such as immunocompromised individuals $(29,35,42)$. The level of Abs with cross-reactivity against different SARS-CoV-2 VOCs is also enhanced by a booster $(33,36)$. This finding suggests that a high level of SARSCoV-2-specific Abs maintained by repeated immunizations is sufficient to control COVID-19 caused by existing antigenic variants. Recent real-world data from Israel show that a third dose of an mRNA vaccine substantially reduced the risk of infection or severe illness caused by the Delta variant (33). Similarly, a recent large-scale study from Chile also showed that 2 doses of an inactivated vaccine followed by a third dose of an inactivated, mRNA or adenovirus-based vaccine enhanced the vaccineinduced protection against SARS-CoV-2 (Chile Ministry of Health, unpublished data). In a preliminary study of 458 mix and match mRNA and Ad vector vaccine booster recipients, substantial increased NAb responses occurred in all recipients post-homologous or heterologous booster vaccination, including against Delta and Beta variants, even in the absence of pre-boost NAb titers (39). Likewise, NHPs boosted 6 months after the primary mRNA 1273 vaccination with either homologous mRNA 1273 or heterologous Beta variant (mRNA 1273Beta) developed broader NAb titers to the Beta and Delta variants and protection to Beta variant challenge (43).

Although the protective role of vaccine-induced T cell responses against COVID-19 is not clear, these responses are induced by different types of SARS-CoV-2 vaccines $(5,6,14,44)$. Cross-reactive T cell responses against different VOCs can be stimulated by vaccination (14), indicating that conserved epitopes are shared by SARS-CoV-2 antigenic variants. Such T cell responses can be further boosted by a third dose (36). A study on transplant patients showed that T cell responses can be detected in the majority of patients after a booster (37). Assuming these vaccine-induced T cell responses have a protective role against COVID-19, a third dose of vaccine might increase the chance of inducing an addition level of protection to immunocompromised patients or poor vaccine responders. Together, 
Burckhardt, et al.

these data demonstrate that there are some short-term benefits of using a booster dose to enhance vaccine-protective effects in adults, especially for vulnerable populations.

Several studies have demonstrated that SARS-CoV-2 vaccine boosters are safe for adults $(36,45$, 46). In these studies, adverse reactions induced by a booster of mRNA or Ad vectored vaccine usually are mild and are comparable to those caused by the second dose of an mRNA vaccine. Thus far, there is no evidence that a COVID-19 vaccine booster shot can induce any unexpected adverse reactions or additional risk of having severe adverse reactions. Although there is no short-term safety concern for a booster dose, the long-term immune consequences of repeated immunizations are not known. Studies have shown that repeated administration of influenza vaccine boosters within a short time (e.g., 2 doses/year) may result in blunting of vaccine-induced antibody responses (47). As SARS-CoV-2 continues to evolve in humans, we do not know whether repeated immunization of the same antigens would induce undesirable immune imprinting effects, thereby skewing the breadth of our immune response in our future encounters of other novel SARS-CoV-2 antigenic variants. Some preliminary studies on vaccine-induced immune responses in recovered COVID-19 individuals argue against this possibility (14, 15); however, further characterization of $A b$ and $T$ and $B$ cell immune memory responses and their longevity in individuals who have received multiple doses of COVID-19 vaccines are still needed.

\section{Herd Immunity is Achieved Via Global Vaccination}

Vaccines not only protect individuals from infectious disease, but also protect those who are unable to be vaccinated and those for whom vaccinations are less effective. That is, vaccines protect the community as well as the individual (48). This protection is called "herd immunity." As the proportion of immune individuals in a population rises, the proportion of susceptible individuals declines, and consequently, the probability of an infected individual encountering a susceptible individual also declines. Theoretically, there is a threshold beyond which the proportion of immune individuals is so 
Burckhardt, et al.

Science of COVID-19 boosters

large that infected individuals are likely to recover before spreading infections to susceptible individuals. Once the herd immunity threshold is exceeded, the rate at which new infections are initiated will be insufficient to sustain the epidemic and eventually the epidemic will subside.

It is important to note, however, that the herd immunity threshold is not a fixed parameter. The herd immunity threshold will vary, even in the midst of an epidemic, according to the characteristics of the virus and the population in which it is spreading. Relevant virus properties may include infectivity, transmissibility and durability outside a host. Important population parameters may include contact rates between individuals, behavioral interventions such as masking, availability of treatments and population clustering. All of these characteristics can be subsumed under a single parameter termed $R_{0}$ or R naught, which is defined as the expected number of new infections generated by an infected individual in a population of susceptible individuals (49). If $R_{0}>1$, then an epidemic will persist; and conversely if $R_{0}<1$, then an epidemic will wane. The herd immunity threshold relates to $R_{0}$ in that it must be equal or greater than $1-1 / R_{0}$ in order to arrest an epidemic (49). For example, if a virus's $R_{0}=4$, then the herd immunity threshold $=0.75$, meaning that $75 \%$ of the population must be rendered immune to infection in order to stop this virus's continuing transmission.

So when will we achieve herd immunity to SARS-CoV-2? How will vaccine boosters affect this timeline? To answer these questions, it is helpful to consider how $R_{0}$ is embedded in an approach to epidemiological theory called compartmental models. In their simplest form, compartmental models assign individuals in a population to one of three categories: susceptible, infectious and removed. Infectious individuals are generated when susceptible individuals are infected by a pathogen, which occurs at a transmission rate, 6 . Individuals are removed from the infectious compartment at a rate $\gamma$ when they recover from infection, succumb to infection or are quarantined. Vaccinated individuals transition directly from the susceptible compartment to the removed compartment, and are included in the removal rate, $\gamma$. In deceptively simple terms, $\mathrm{R}_{0} \approx 6 / \gamma(49)$. 
Burckhardt, et al.

It must be recognized that $B$ and $\gamma$ vary over time and place. $B$ may increase with virus evolution, as is seen with the highly transmissible SARS-Cov-2 Delta variant (50), or due to host behavioral changes such as reduced mask usage and social distancing. Removal rate $\gamma$ may increase with improved treatments and expanded vaccine access. Furthermore, except in cases of death, residence in the removed compartment is not permanent. Vaccines are not $100 \%$ effective and breakthrough infections occur (51). Reinfections of individuals who have recovered from COVID-19 are also possible (52). Immunity, whether vaccine-induced or natural, wanes. SARS-CoV-2 vaccine booster shots will reduce reversions to virus susceptibility (33).

As of the time of writing, there have been 250 million confirmed COVID-19 cases globally (https://covid19.who.int/), but this number is almost certainly an underestimate. Roughly extrapolating from US data suggesting that $60 \%$ of infections have gone unreported (53), actual global cases may number $\sim 615$ million. In addition, an estimated 4.02 billion people have received at least one dose of a SARS-CoV-2 vaccine (https://www.nytimes.com/interactive/2021/world/covid-vaccinationstracker.html). Thus, the removed category may contain as many as 4.5 billion individuals, or $\sim 57 \%$ of the world population. Despite the difficulties estimating $\mathrm{R}_{0}$, as alluded to above, it would appear that herd immunity threshold is approaching, but some wonder whether herd immunity to SARS-CoV-2 will ever be achieved (54). The UK may be an important indicator. Although $68 \%$ of the population is fully vaccinated and at least $13.5 \%$ have recovered from infection, the UK reported an average of 41,326 cases per day in the last week of October, 2021, a number that has remained relatively stable since July 2021 (https://covid19.who.int/).

The UK situation reflects an important axiom regarding herd immunity: we won't get there unless we all get there. No country can hope to escape the pandemic by itself. Concerningly, vaccine distribution has been uneven. Much of the Global South remains unvaccinated. Even in countries where availability is high, vaccine hesitancy limits full uptake. Slow or incomplete vaccine uptake prolongs the 
Burckhardt, et al.

Science of COVID-19 boosters

246

247

epidemic and exacerbates other issues, namely waning immunity and pandemic-fatigue. Remaining vigilant and engaging in protective behaviors is draining and lapses become increasingly likely. Collectively these factors permit continuing virus evolution and the accession of mutations enhancing virus transmission and evasion of antibody mediated neutralization. New variants may emerge that negate our progress unless we ensure protection for the entire global community. In record time, a multitude of safe and effective COVID-19 vaccines have been developed. Yet, as with most vaccines, immunity wanes, and this coupled with the emergence of SARS-CoV-2 variants has led to increases in breakthrough infections. Booster doses have been shown to be safe and increase SARS-CoV-2-specific neutralizing antibody levels that are cross-reactive to current VOCs. This is especially important for protecting elderly and immunocompromised individuals who are at highest risk for severe COVID-19.

However, current vaccines provide highly effective and sustained protection against COVID-19related hospitalizations and deaths across age groups, indicating that a booster dose may not be needed for all fully vaccinated individuals. Additionally, reaching herd immunity requires equitable vaccine distribution and access worldwide. Resources spent on administering booster doses may prolong unequal global vaccine distribution as well as increase vaccine hesitancy. Public health officials and policy makers should take these factors into consideration when deciding what groups should receive boosters and when. 


\section{References}

1. Krause PR, Fleming TR, Peto R, Longini IM, Figueroa JP, Sterne JAC, Cravioto A, Rees H, Higgins JPT, Boutron I, Pan H, Gruber MF, Arora N, Kazi F, Gaspar R, Swaminathan S, Ryan MJ, HenaoRestrepo AM. 2021. Considerations in boosting COVID-19 vaccine immune responses. Lancet 398:1377-1380.

2. Muller L, Andree M, Moskorz W, Drexler I, Walotka L, Grothmann R, Ptok J, Hillebrandt J, Ritchie A, Rabl D, Ostermann PN, Robitzsch R, Hauka S, Walker A, Menne C, Grutza R, Timm J, Adams O, Schaal H. 2021. Age-dependent immune response to the Biontech/Pfizer BNT162b2 COVID-19 vaccination. Clin Infect Dis doi:10.1093/cid/ciab381.

3. Doria-Rose N, Suthar MS, Makowski M, O'Connell S, McDermott AB, Flach B, Ledgerwood JE, Mascola JR, Graham BS, Lin BC, O'Dell S, Schmidt SD, Widge AT, Edara VV, Anderson EJ, Lai L, Floyd K, Rouphael NG, Zarnitsyna V, Roberts PC, Makhene M, Buchanan W, Luke CJ, Beigel JH, Jackson LA, Neuzil KM, Bennett H, Leav B, Albert J, Kunwar P, m RNASG. 2021. Antibody Persistence through 6 Months after the Second Dose of mRNA-1273 Vaccine for Covid-19. N Engl J Med 384:2259-2261.

4. Kertes J, Gez SB, Saciuk Y, Supino-Rosin L, Stein NS, Mizrahi-Reuveni M, Zohar AE. 2021. Effectiveness of the mRNA BNT162b2 vaccine six months after vaccination: findings from a large Israeli HMO. medRxiv doi:https://doi.org/10.1101/2021.09.01.21262957.

5. Pegu A, O'Connell SE, Schmidt SD, O'Dell S, Talana CA, Lai L, Albert J, Anderson E, Bennett H, Corbett KS, Flach B, Jackson L, Leav B, Ledgerwood JE, Luke CJ, Makowski M, Nason MC, Roberts PC, Roederer M, Rebolledo PA, Rostad CA, Rouphael NG, Shi W, Wang L, Widge AT, Yang ES, Beigel JH, Graham BS, Mascola JR, Suthar MS, McDermott AB, Doria-Rose NA, Arega J, Beigel JH, Buchanan W, Elsafy M, Hoang B, Lampley R, Kolhekar A, Koo H, Luke C, Makhene M, Nayak S, Pikaart-Tautges R, Roberts PC, Russell J, Sindall E, Albert J, Kunwar P, Makowski M, et al. 2021. Durability of mRNA-1273 vaccine-induced antibodies against SARS-CoV-2 variants. Science 373:1372-1377.

6. Sahin U, Muik A, Derhovanessian E, Vogler I, Kranz LM, Vormehr M, Baum A, Pascal K, Quandt J, Maurus D, Brachtendorf S, Lorks V, Sikorski J, Hilker R, Becker D, Eller AK, Grutzner J, Boesler C, Rosenbaum C, Kuhnle MC, Luxemburger U, Kemmer-Bruck A, Langer D, Bexon M, Bolte S, Kariko K, Palanche T, Fischer B, Schultz A, Shi PY, Fontes-Garfias C, Perez JL, Swanson KA, Loschko J, Scully IL, Cutler M, Kalina W, Kyratsous CA, Cooper D, Dormitzer PR, Jansen KU, Tureci O. 2020. COVID-19 vaccine BNT162b1 elicits human antibody and TH1 T cell responses. Nature 586:594599.

7. Corbett KS, Flynn B, Foulds KE, Francica JR, Boyoglu-Barnum S, Werner AP, Flach B, O'Connell S, Bock KW, Minai M, Nagata BM, Andersen H, Martinez DR, Noe AT, Douek N, Donaldson MM, Nji NN, Alvarado GS, Edwards DK, Flebbe DR, Lamb E, Doria-Rose NA, Lin BC, Louder MK, O'Dell S, Schmidt SD, Phung E, Chang LA, Yap C, Todd JM, Pessaint L, Van Ry A, Browne S, Greenhouse J, Putman-Taylor T, Strasbaugh A, Campbell TA, Cook A, Dodson A, Steingrebe K, Shi W, Zhang Y, Abiona OM, Wang L, Pegu A, Yang ES, Leung K, Zhou T, Teng IT, Widge A, et al. 2020. Evaluation of the mRNA-1273 Vaccine against SARS-CoV-2 in Nonhuman Primates. N Engl J Med 383:15441555.

8. Earle KA, Ambrosino DM, Fiore-Gartland A, Goldblatt D, Gilbert PB, Siber GR, Dull P, Plotkin SA. 2021. Evidence for antibody as a protective correlate for COVID-19 vaccines. Vaccine 39:44234428.

9. Khoury DS, Cromer D, Reynaldi A, Schlub TE, Wheatley AK, Juno JA, Subbarao K, Kent SJ, Triccas JA, Davenport MP. 2021. Neutralizing antibody levels are highly predictive of immune protection from symptomatic SARS-CoV-2 infection. Nat Med 27:1205-1211. 
10. Cho A, Muecksch F, Schaefer-Babajew D, Wang Z, Finkin S, Gaebler C, Ramos V, Cipolla M, Mendoza P, Agudelo M, Bednarski E, DaSilva J, Shimeliovich I, Dizon J, Daga M, Millard K, Turroja M, Schmidt F, Zhang F, Tanfous TB, Jankovic M, Oliveria TY, Gazumyan A, Caskey M, Bieniasz PD, Hatziioannou T, Nussenzweig MC. 2021. Anti-SARS-CoV-2 receptor binding domain antibody evolution after mRNA vaccination. Nature doi:10.1038/s41586-021-04060-7.

11. Dan JM, Mateus J, Kato Y, Hastie KM, Yu ED, Faliti CE, Grifoni A, Ramirez SI, Haupt S, Frazier A, Nakao C, Rayaprolu V, Rawlings SA, Peters B, Krammer F, Simon V, Saphire EO, Smith DM, Weiskopf D, Sette A, Crotty S. 2021. Immunological memory to SARS-CoV-2 assessed for up to 8 months after infection. Science 371.

12. Sette A, Crotty S. 2021. Adaptive immunity to SARS-CoV-2 and COVID-19. Cell 184:861-880.

13. Vanshylla K, Di Cristanziano V, Kleipass F, Dewald F, Schommers P, Gieselmann L, Gruell H, Schlotz M, Ercanoglu MS, Stumpf R, Mayer P, Zehner M, Heger E, Johannis W, Horn C, Suarez I, Jung N, Salomon S, Eberhardt KA, Gathof B, Fatkenheuer G, Pfeifer N, Eggeling R, Augustin M, Lehmann C, Klein F. 2021. Kinetics and correlates of the neutralizing antibody response to SARSCoV-2 infection in humans. Cell Host Microbe 29:917-929 e4.

14. Goel RR, Painter MM, Apostolidis SA, Mathew D, Meng W, Rosenfeld AM, Lundgreen KA, Reynaldi A, Khoury DS, Pattekar A, Gouma S, Kuri-Cervantes L, Hicks P, Dysinger S, Hicks A, Sharma $H$, Herring $S$, Korte $S$, Baxter AE, Oldridge DA, Giles JR, Weirick ME, McAllister CM, Awofolaju M, Tanenbaum N, Drapeau EM, Dougherty J, Long S, D'Andrea K, Hamilton JT, McLaughlin M, Williams JC, Adamski S, Kuthuru O, Frank I, Betts MR, Vella LA, Grifoni A, Weiskopf D, Sette A, Hensley SE, Davenport MP, Bates P, Luning Prak ET, Greenplate AR, Wherry EJ, Adamski S, Alam Z, Addison MM, Byrne KT, et al. 2021. mRNA vaccines induce durable immune memory to SARS-CoV-2 and variants of concern. Science doi:10.1126/science.abm0829:eabm0829.

15. Goel RR, Apostolidis SA, Painter MM, Mathew D, Pattekar A, Kuthuru O, Gouma S, Hicks P, Meng W, Rosenfeld AM, Dysinger S, Lundgreen KA, Kuri-Cervantes L, Adamski S, Hicks A, Korte S, Oldridge DA, Baxter AE, Giles JR, Weirick ME, McAllister CM, Dougherty J, Long S, D'Andrea K, Hamilton JT, Betts MR, Luning Prak ET, Bates P, Hensley SE, Greenplate AR, Wherry EJ. 2021. Distinct antibody and memory $B$ cell responses in SARS-CoV-2 naive and recovered individuals following mRNA vaccination. Sci Immunol 6.

16. Wang Z, Muecksch F, Schaefer-Babajew D, Finkin S, Viant C, Gaebler C, Hoffmann HH, Barnes CO, Cipolla M, Ramos V, Oliveira TY, Cho A, Schmidt F, Da Silva J, Bednarski E, Aguado L, Yee J, Daga M, Turroja M, Millard KG, Jankovic M, Gazumyan A, Zhao Z, Rice CM, Bieniasz PD, Caskey $M$, Hatziioannou T, Nussenzweig MC. 2021. Naturally enhanced neutralizing breadth against SARS-CoV-2 one year after infection. Nature 595:426-431.

17. Gazit S, Shlezinger R, Perez G, Lotan R, Peretz A, Ben-Tov A, Cohen D, Muhsen K, Chodick G, Patalon T. 2021. Comparing SARS-CoV-2 natural immunity to vaccine-induced immunity: reinfections versus breakthrough infections. medRxiv doi:https://doi.org/10.1101/2021.08.24.21262415.

18. Bozio CH, Grannis SJ, Naleway AL, Ong TC, Butterfield KA, DeSilva MB, Natarajan K, Yang DH, Rao S, Klein NP, Irving SA, Dixon BE, Dascomb K, Liao IC, Reynolds S, McEvoy C, Han J, Reese SE, Lewis N, Fadel WF, Grisel N, Murthy K, Ferdinands J, Kharbanda AB, Mitchell PK, Goddard K, Embi PJ, Arndorfer J, Raiyani C, Patel P, Rowley EA, Fireman B, Valvi NR, Griggs EP, Levy ME, Zerbo O, Porter RM, Birch RJ, Blanton L, Ball SW, Steffens A, Olson N, Williams J, Dickerson M, McMorrow M, Schrag SJ, Verani JR, Fry AM, Azziz-Baumgartner E, Barron M, et al. 2021. LaboratoryConfirmed COVID-19 Among Adults Hospitalized with COVID-19-Like Illness with InfectionInduced or mRNA Vaccine-Induced SARS-CoV-2 Immunity - Nine States, January-September 2021. MMWR Morb Mortal Wkly Rep 70:1539-1544. 
Burckhardt, et al.

Science of COVID-19 boosters

360

361

362

363

364

365

366

367

368

369

370

371

372

373

374

375

376

377

378

379

380

381

382

383

384

385

386

387

388

389

390

391

392

393

394

395

396

397

398

399

400

401

402

403

404

405

406

407

19. Lau EHY, Tsang OTY, Hui DSC, Kwan MYW, Chan W-h, Chiu SS, Ko RLW, Chan KH, Cheng SMS, Perera RAPM, Cowling BJ, Poon LLM, Peiris M. 2021. Neutralizing antibody titres in SARS-CoV-2 infections. Nature Communications 12:63.

20. Tarke A, Sidney J, Methot N, Yu ED, Zhang Y, Dan JM, Goodwin B, Rubiro P, Sutherland A, Wang E, Frazier A, Ramirez SI, Rawlings SA, Smith DM, da Silva Antunes R, Peters B, Scheuermann RH, Weiskopf D, Crotty S, Grifoni A, Sette A. 2021. Impact of SARS-CoV-2 variants on the total CD4(+) and CD8(+) T cell reactivity in infected or vaccinated individuals. Cell Rep Med 2:100355.

21. Cohen KW, Linderman SL, Moodie Z, Czartoski J, Lai L, Mantus G, Norwood C, Nyhoff LE, Edara VV, Floyd K, De Rosa SC, Ahmed H, Whaley R, Patel SN, Prigmore B, Lemos MP, Davis CW, Furth S, O'Keefe JB, Gharpure MP, Gunisetty S, Stephens K, Antia R, Zarnitsyna VI, Stephens DS, Edupuganti S, Rouphael N, Anderson EJ, Mehta AK, Wrammert J, Suthar MS, Ahmed R, McElrath MJ. 2021. Longitudinal analysis shows durable and broad immune memory after SARS-CoV-2 infection with persisting antibody responses and memory B and T cells. Cell Rep Med 2:100354.

22. Townsend JP, Hassler HB, Wang Z, Miura S, Singh J, Kumar S, Ruddle NH, Galvani AP, Dornburg A. 2021. The durability of immunity against reinfection by SARS-CoV-2: a comparative evolutionary study. Lancet Microbe doi:10.1016/s2666-5247(21)00219-6.

23. Romano CM, Felix AC, Paula AV, Jesus JG, Andrade PS, Candido D, Oliveira FM, Ribeiro AC, Silva FCD, Inemami M, Costa AA, Leal COD, Figueiredo WM, Pannuti CS, Souza WM, Faria NR, Sabino EC. 2021. SARS-CoV-2 reinfection caused by the P.1 lineage in Araraquara city, Sao Paulo State, Brazil. Rev Inst Med Trop Sao Paulo 63:e36.

24. Kuzmina A, Khalaila Y, Voloshin O, Keren-Naus A, Boehm-Cohen L, Raviv Y, Shemer-Avni Y, Rosenberg E, Taube R. 2021. SARS-CoV-2 spike variants exhibit differential infectivity and neutralization resistance to convalescent or post-vaccination sera. Cell Host Microbe 29:522-528 e2.

25. Abu-Raddad LJ, Chemaitelly H, Butt AA, National Study Group for C-V. 2021. Effectiveness of the BNT162b2 Covid-19 Vaccine against the B.1.1.7 and B.1.351 Variants. N Engl J Med 385:187-189.

26. Kamar N, Abravanel F, Marion O, Couat C, Izopet J, Del Bello A. 2021. Three Doses of an mRNA Covid-19 Vaccine in Solid-Organ Transplant Recipients. N Engl J Med 385:661-662.

27. Eyre DW, Taylor D, Purver M, Chapman D, Fowler T, Pouwels KB, Walker AS, Peto TEA. 2021. The impact of SARS-CoV-2 vaccination on Alpha \& Delta variant transmission. medRxiv doi:https://doi.org/10.1101/2021.09.28.21264260.

28. Chia PY, Ong SWX, Chiew CJ, Ang LW, Chavatte JM, Mak TM, Cui L, Kalimuddin S, Chia WN, Tan CW, Chai LYA, Tan SY, Zheng S, Lin RTP, Wang L, Leo YS, Lee VJ, Lye DC, Young BE. 2021. Virological and serological kinetics of SARS-CoV-2 Delta variant vaccine-breakthrough infections: a multi-center cohort study. medRxiv doi:https://doi.org/10.1101/2021.07.28.21261295.

29. Shamier MC, Tostmann A, Bogers S, de Wilde J, IJpelaar J, van der Kleij WA, de Jager H, Haagmans BL, Molenkamp R, Munnink BBO, van Rossum C, Rahamat-Langendoen J, van der Geest N, Bleeker-Rovers CP, Wertheim H, Koopmans MPG, GeurtsvanKessel CH. 2021. Virological characteristics of SARS-CoV-2 vaccine breakthrough infections in health care workers. medRxiv doi:https://doi.org/10.1101/2021.08.20.21262158.

30. Singanayagam A, Hakki S, Dunning J, Madon KJ, Crone MA, Koycheva A, Derqui-Fernandez N, Barnett JL, Whitfield MG, Varro R, Charlett A, Kundu R, Fenn J, Cutajar J, Quinn V, Conibear E, Barclay W, Freemont PS, Taylor GP, Ahmad S, Zambon M, Ferguson NM, Lalvani A, Badhan A, Dustan S, Tejpal C, Ketkar AV, Narean JS, Hammett S, McDermott E, Pillay T, Houston H, Luca C, Samuel J, Bremang S, Evetts S, Poh J, Anderson C, Jackson D, Miah S, Ellis J, Lackenby A. Community transmission and viral load kinetics of the SARS-CoV-2 delta (B.1.617.2) variant in vaccinated and unvaccinated individuals in the UK: a prospective, longitudinal, cohort study. The Lancet Infectious Diseases doi:10.1016/S1473-3099(21)00648-4. 
Burckhardt, et al.

Science of COVID-19 boosters

31. Neidleman J, Luo X, McGregor M, Xie G, Murray V, Greene WC, Lee SA, Roan NR. 2021. mRNA vaccine-induced $T$ cells respond identically to SARS-CoV-2 variants of concern but differ in longevity and homing properties depending on prior infection status. Elife 10.

32. Saif LJ. 2020. Vaccines for COVID-19: perspectives, prospects, and challenges based on candidate SARS, MERS, and animal coronavirus vaccines. Eur Med J doi:10.33590/emj/200324.

33. Bar-On YM, Goldberg Y, Mandel M, Bodenheimer O, Freedman L, Kalkstein N, Mizrahi B, AlroyPreis S, Ash N, Milo R, Huppert A. 2021. Protection of BNT162b2 Vaccine Booster against Covid19 in Israel. N Engl J Med 385:1393-1400.

34. Bensouna I, Caudwell V, Kubab S, Acquaviva S, Pardon A, Vittoz N, Bozman DF, Hanafi L, Faucon AL, Housset P. 2021. SARS-CoV-2 Antibody Response After a Third Dose of the BNT162b2 Vaccine in Patients Receiving Maintenance Hemodialysis or Peritoneal Dialysis. Am J Kidney Dis doi:10.1053/j.ajkd.2021.08.005.

35. Bertrand D, Hamzaoui M, Lemée V, Lamulle J, Laurent C, Etienne I, Lemoine M, Lebourg L, Hanoy M, Le Roy F, Nezam D, Farce F, Plantier JC, Boyer O, Guerrot D, Candon S. 2021. Antibody and Tcell response to a third dose of SARS-CoV-2 mRNA BNT162b2 vaccine in kidney transplant recipients. Kidney Int doi:10.1016/j.kint.2021.09.014.

36. Flaxman A, Marchevsky NG, Jenkin D, Aboagye J, Aley PK, Angus B, Belij-Rammerstorfer S, Bibi S, Bittaye M, Cappuccini F, Cicconi P, Clutterbuck EA, Davies S, Dejnirattisai W, Dold C, Ewer KJ, Folegatti PM, Fowler J, Hill AVS, Kerridge S, Minassian AM, Mongkolsapaya J, Mujadidi YF, Plested E, Ramasamy MN, Robinson H, Sanders H, Sheehan E, Smith H, Snape MD, Song R, Woods D, Screaton G, Gilbert SC, Voysey M, Pollard AJ, Lambe T. 2021. Reactogenicity and immunogenicity after a late second dose or a third dose of ChAdOx1 nCoV-19 in the UK: a substudy of two randomised controlled trials (COV001 and COV002). Lancet 398:981-990.

37. Peled Y, Ram E, Lavee J, Segev A, Matezki S, Wieder-Finesod A, Halperin R, Mandelboim M, Indenbaum V, Levy I, Sternik L, Raanani E, Afek A, Kreiss Y, Lustig Y, Rahav G. 2021. Third dose of the BNT162b2 vaccine in heart transplant recipients: Immunogenicity and clinical experience. J Heart Lung Transplant doi:10.1016/j.healun.2021.08.010.

38. Sadarangani M, Marchant A, Kollmann TR. 2021. Immunological mechanisms of vaccine-induced protection against COVID-19 in humans. Nature Reviews Immunology 21:475-484.

39. Atmar RL, Lyke KE, Deming ME, Jackson LA, Branche AR, El Sahly HM, Rostad CA, Martin JM, Johnston C, Rupp RE, Mulligan MJ, Brady RC, Frenck RW, Bäcker M, Kottkamp AC, Babu TM, Rajakumar K, Edupuganti S, Dobryzynski D, Posavad CM, Archer JI, Crandon S, Nayak SU, Szydlo $D$, Zemanek J, Islas CPD, Brown ER, Suthar MS, McElrath MJ, McDermott AB, O'Connell SE, Montefiori DC, Eaton A, Neuzil KM, Stephens DS, Roberts PC, Beigel JH. 2021. Heterologous SARS-CoV-2 Booster Vaccinations - Preliminary Report. medRxiv doi:10.1101/2021.10.10.21264827.

40. Yang S, Li Y, Dai L, Wang J, He P, Li C, Fang X, Wang C, Zhao X, Huang E, Wu C, Zhong Z, Wang F, Duan X, Tian S, Wu L, Liu Y, Luo Y, Chen Z, Li F, Li J, Yu X, Ren H, Liu L, Meng S, Yan J, Hu Z, Gao L, Gao GF. 2021. Safety and immunogenicity of a recombinant tandem-repeat dimeric RBD-based protein subunit vaccine (ZF2001) against COVID-19 in adults: two randomised, double-blind, placebo-controlled, phase 1 and 2 trials. Lancet Infect Dis 21:1107-1119.

41. Yue L, Xie T, Yang T, Zhou J, Chen H, Zhu H, Li H, Xiang H, Wang J, Yang H, Zhao H, Wei X, Zhang $\mathrm{Y}, \mathrm{Xie}$ Z. 2021. A third booster dose may be necessary to mitigate neutralizing antibody fading after inoculation with two doses of an inactivated SARS-CoV-2 vaccine. J Med Virol doi:10.1002/jmv.27334.

42. Benotmane I, Gautier G, Perrin P, Olagne J, Cognard N, Fafi-Kremer S, Caillard S. 2021. Antibody Response After a Third Dose of the mRNA-1273 SARS-CoV-2 Vaccine in Kidney Transplant Recipients With Minimal Serologic Response to 2 Doses. Jama 326:1063-5. 
Burckhardt, et al.

Science of COVID-19 boosters

456

457

458

459

460

461

462

463

464

465

466

467

468

469

470

471

472

473

474

475

476

477

478

479

480

481

482

483

484

485

486

487

488

489

490

491

43. Corbett KS, Gagne M, Wagner DA, S OC, Narpala SR, Flebbe DR, Andrew SF, Davis RL, Flynn B, Johnston TS, Stringham CD, Lai L, Valentin D, Van Ry A, Flinchbaugh Z, Werner AP, Moliva JI, Sriparna M, O'Dell S, Schmidt SD, Tucker C, Choi A, Koch M, Bock KW, Minai M, Nagata BM, Alvarado GS, Henry AR, Laboune F, Schramm CA, Zhang Y, Yang ES, Wang L, Choe M, BoyogluBarnum S, Wei S, Lamb E, Nurmukhambetova ST, Provost SJ, Donaldson MM, Marquez J, Todd JM, Cook A, Dodson A, Pekosz A, Boritz E, Ploquin A, Doria-Rose N, Pessaint L, Andersen H, et al. 2021. Protection against SARS-CoV-2 beta variant in mRNA-1273 vaccine-boosted nonhuman primates. Science doi:10.1126/science.abl8912:eabl8912.

44. Deng Y, Li Y, Yang R, Tan W. 2021. SARS-CoV-2-specific T cell immunity to structural proteins in inactivated COVID-19 vaccine recipients. Cell Mol Immunol 18:2040-2041.

45. Hause AM, Baggs J, Gee J, Marquez P, Myers TR, Shimabukuro TT, Shay DK. 2021. Safety Monitoring of an Additional Dose of COVID-19 Vaccine - United States, August 12-September 19, 2021. MMWR Morb Mortal Wkly Rep 70:1379-1384.

46. Shapiro Ben David S, Shamir-Stein N, Baruch Gez S, Lerner U, Rahamim-Cohen D, Ekka Zohar A. 2021. Reactogenicity of a third BNT162b2 mRNA COVID-19 vaccine among immunocompromised individuals and seniors - A nationwide survey. Clin Immunol 232:108860.

47. Tam YH, Valkenburg SA, Perera R, Wong JHF, Fang VJ, Ng TWY, Kwong ASK, Tsui WWS, Ip DKM, Poon LLM, Chau CKV, Barr IG, Peiris JSM, Cowling BJ. 2018. Immune Responses to Twice-Annual Influenza Vaccination in Older Adults in Hong Kong. Clin Infect Dis 66:904-912.

48. Anderson RM, May RM. 1985. Vaccination and herd immunity to infectious diseases. Nature 318:323-329.

49. Hethcote HW. 2000. The Mathematics of Infectious Diseases. SIAM Review 42:599-653.

50. Dagpunar J. 2021. Interim estimates of increased transmissibility, growth rate, and reproduction number of the Covid-19 B.1.617.2 variant of concern in the United Kingdom. medRxiv doi:10.1101/2021.06.03.21258293:2021.06.03.21258293.

51. Hacisuleyman E, Hale C, Saito Y, Blachere NE, Bergh M, Conlon EG, Schaefer-Babajew DJ, DaSilva J, Muecksch F, Gaebler C, Lifton R, Nussenzweig MC, Hatziioannou T, Bieniasz PD, Darnell RB. 2021. Vaccine Breakthrough Infections with SARS-CoV-2 Variants. New England Journal of Medicine 384:2212-2218.

52. Babiker A, Marvil CE, Waggoner JJ, Collins MH, Piantadosi A. 2021. The Importance and Challenges of Identifying SARS-CoV-2 Reinfections. J Clin Microbiol 59.

53. Irons NJ, Raftery AE. 2021. Estimating SARS-CoV-2 infections from deaths, confirmed cases, tests, and random surveys. Proc Natl Acad Sci U S A 118.

54. Aschwanden C. 2021. Five reasons why COVID herd immunity is probably impossible. Nature 591:520-522. 